\title{
A Novel Nuclear Export Inhibitor JBIR-02, a New Piericidin Discovered from Streptomyces sp. ML55
}

\author{
Jun-ya Ueda, Takushi Togashi, Susumu Matukura, Aya Nagai, Takuji Nakashima, \\ Hisayuki Komaki, Kozue Anzai, Shigeaki Harayama, Takayuki Doi, Takashi Takahashi, \\ Tohru Natsume, Yasutomo Kisu, Naoki Goshima, Nobuo Nomura, Motoki Takagi, \\ Kazuo Shin-ya
}

Received: May 21, 2007 / Accepted: June 29, 2007

(C) Japan Antibiotics Research Association

\begin{abstract}
A new member of the piericidin family, JBIR02, was isolated from mycelium of Streptomyces sp. ML55 together with two known piericidin derivatives, piericidin $\mathrm{A}_{1}$ and IT-143-B. The structure was determined on the basis of spectroscopic data. JBIR-02 inhibited nuclear export of $\beta$-arrestin in HeLa cells at the concentration of $20 \mu \mathrm{M}$.
\end{abstract}

Keywords piericidin, JBIR-02, Streptomyces sp., nuclear transport, leptomycin

Arrestins are a family of scaffolding proteins that are closely associated with the function of seven transmembrane domain $G$ protein-coupled receptors (GPCRs). In mammals, four subtypes of the arrestin family are $\beta$-arrestin 1, $\beta$-arrestin 2, visual arrestin and conspecific arrestin. $\beta$-Arrestins 1 and 2 are expressed ubiquitously in various organs, whereas visual arrestin is restricted to photoreceptor cells. These proteins promote the internalization and desensitization of GPCRs $[1,2]$. In

K. Shin-ya (Corresponding author), T. Natsume, Y. Kisu, N. Goshima, N. Nomura: Biological Information Research Center (BIRC), National Institute of Advanced Industrial Science and Technology (AIST), 2-42 Aomi, Koto-ku, Tokyo 135-0064, Japan, E-mail: kshinya@jbirc.aist.go.jp

M. Takagi (Corresponding author), J. Ueda, T. Togashi, S. Matukura, A. Nagai: Japan Biological Information Research Center (JBIRC), Japan Biological Informatics Consortium (JBIC), 2-42 Aomi, Koto-ku, Tokyo 135-0064, Japan,

E-mail: mtakagi@jbirc.aist.go.jp addition to the conventional functions of arrestins, recent reports revealed the new roles for $\beta$-arrestins in nuclear functions [3 5]. Arrestins have nuclear localization and nuclear exclusion signals and shuttle between the nucleus and the cytoplasm. $\beta$-Arrestin regulation has been demonstrated for an ever-increasing number of signaling molecules including the mitogen-activated protein kinases ERK, JNK, and p38 as well as Akt, PI3 kinase, and RhoA. The signaling capacities of these versatile adapter molecules are involved in the possible implications for cellular processes such as chemotaxis and apoptosis. Thus, the compounds which regulate the translocation of arrestin are expected to be new type of antitumor drugs. In the course of our screening program for regulators of arrestin translocation, we isolated a new piericidin derivative, designated as JBIR-02 (1, Fig. 1), from mycelium of Streptomyces sp. ML55.

The Streptomyces sp. ML55 isolated from a soil sample collected in Taketomi Island, Okinawa Prefecture, Japan, was cultured at $27^{\circ} \mathrm{C}$ for 5 days in $500-\mathrm{ml}$ Erlenmeyer flasks containing a medium consisting of $2.0 \%$ glycerin,

T. Nakashima, H. Komaki, K. Anzai, S. Harayama: NITE Biological Resource Center (NBRC), National Institute of Technology and Evaluation (NITE), 2-5-8 Kazusakamatari, Kisarazu, Chiba 292-0818, Japan

T. Doi, T. Takahashi: Graduate School of Science and Engineering, Tokyo Institute of Technology, 2-12-1 Ookayama, Meguro-ku, Tokyo 152-8552, Japan 
<smiles>CC=C(C)C=C(C)C(O)C(C)C=C(C)C=CCC(C)=CCc1[nH]c(OC)cc(=O)c1C</smiles><smiles>C/C=C(C)/C=C(\C)C(O)C(C)/C=C(C)/C=C/C/C(C)=C/Cc1nc(OC)cc(O)c1C</smiles>

1<smiles>CC=C(C)C(O)C(C)C=C(C)C=CCC(C)=CCc1nc(OC)c(OC)c(O)c1C</smiles><smiles>CC=C(C)C=C(C)C(O)C(C)C=C(C)C=CCC(C)=CCc1nc(OC)c(OC)c(O)c1C</smiles>

Fig. 1 Structures of JBIR-02 (1), piericidin $A_{1}$ (2) and IT-143-B (3).

$1.0 \%$ molasses, $0.5 \%$ casein, $0.1 \%$ polypepton, $0.4 \%$ $\mathrm{CaCO}_{3}$ (pH 7.2 before sterilization). The mycelium from the cultured broth (2 liters) was extracted with acetone. After concentrated in vacuo, the residue was extracted with EtOAc for two times. The ethyl acetate layer was dried over $\mathrm{Na}_{2} \mathrm{SO}_{4}$, and concentrated in vacuo. The dried residue was applied to normal-phase MPLC (Purif-Pack SI-60, Moritex) and developed with a $n$-hexane-EtOAc linear gradient system to yield two active fractions $(40 \sim 50 \%$ and $90 \sim 100 \%$ EtOAc eluents). The second active eluate (90 100\% EtOAc) was subjected to preparative reversedphase HPLC $\left(85 \% \mathrm{MeOH}-\mathrm{H}_{2} \mathrm{O}\right.$, Senshu Pak PEGASIL ODS 20 i.d. $\times 250 \mathrm{~mm})$ to yield $\mathbf{1}(3.2 \mathrm{mg}, \mathrm{Rt}=21.0$ minutes) as an active compound. Piericidin $\mathrm{A}_{1}(2,10.4 \mathrm{mg})$ [6] and IT-143-B $(3,13.7 \mathrm{mg})$ [7] which existed in the first MPLC fractions (40 50\% EtOAc eluate) were isolated with reversed-phase MPLC $\left(85 \% \mathrm{MeOH}-\mathrm{H}_{2} \mathrm{O}\right.$, Purif-Pack ODS 100, Moritex).

1 was obtained as a brown amorphous solid. The physico-chemical properties of $\mathbf{1}$ are summarized in Table 1. Its HR-ESI-MS $(\mathrm{m} / \mathrm{z}$ 426.2979) data indicated its molecular formula to be $\mathrm{C}_{27} \mathrm{H}_{39} \mathrm{NO}_{3}$. The UV spectrum of $\mathbf{1}$ resembled those of piericidins, which suggested the presence of 4-hydroxy-pyridine moiety as a chromophore [3 5]. The ${ }^{1} \mathrm{H}-$ and ${ }^{13} \mathrm{C}-\mathrm{NMR}$ data of $\mathbf{1}$ are shown in Table 2. The structure elucidation was carried out mainly
Table 1 Physico-chemical properties of JBIR-02 (1)

\begin{tabular}{ll}
\hline Appearance & Brown amorphous solid \\
MP & $41.0 \sim 50.0^{\circ} \mathrm{C}$ \\
{$[\alpha]_{D}^{25}$} & $-13.0^{\circ}(\mathrm{c} 0.88, \mathrm{MeOH})$ \\
$\mathrm{HR}$-ESI-MS $(\mathrm{m} / \mathrm{z})$ & \\
$\quad$ found & $426.2979(\mathrm{M}+\mathrm{H})^{+}$ \\
$\quad$ calcd & 426.3008 \\
UV $\lambda_{\max }^{\mathrm{MeOH}} \mathrm{nm}(\log \varepsilon)$ & $223(4.5), 240(4.6)$ \\
IR (KBr) $v_{\max } \mathrm{cm}^{-1}$ & $3250,2926,2859,1633,1494,1455$, \\
& $1399,1386,1233$ \\
\hline
\end{tabular}

utilizing the major tautomer of $\mathbf{1}$. The analysis of ${ }^{1} \mathrm{H}-\mathrm{NMR}$ data and ${ }^{1} \mathrm{H}-{ }^{1} \mathrm{H}$ COSY spectra of 1 revealed two sets of signals in 3:1 ratio of intensity, which showed that $\mathbf{1}$ mainly consisted of pyridone structure vide infra. The ${ }^{1} \mathrm{H}-$ ${ }^{1} \mathrm{H}$ COSY spectra of 1 revealed the two 2-butenyl, two propenyl and a 1-hydroxy-2-methyl-3-pentenyl moieties as shown by bold line in Fig. 2. The connectivity of these partial structures was elucidated as follows. The ${ }^{1} \mathrm{H}-{ }^{13} \mathrm{C}$ long range couplings from a methyl proton $3-\mathrm{Me}\left(\delta_{\mathrm{H}} 1.74\right)$ to $\mathrm{C}-4\left(\delta_{\mathrm{C}} 43.1\right)$, from $7-\mathrm{Me}\left(\delta_{\mathrm{H}} 1.79\right)$ to $\mathrm{C}-6\left(\delta_{\mathrm{C}} 136.7\right)$, from 11-Me $\left(\delta_{\mathrm{H}} 1.78\right)$ to $\mathrm{C}-10\left(\delta_{\mathrm{C}} 83.6\right)$ and from $13-\mathrm{Me}$ $\left(\delta_{\mathrm{H}} 1.74\right)$ to $\mathrm{C}-12\left(\delta_{\mathrm{C}} 132.9\right)$ revealed the side chain substructure in $\mathbf{1}$. This side chain moiety was deduced to be substituted at the position of $\mathrm{C}-1^{\prime}$ in pyridone moiety by the ${ }^{1} \mathrm{H}-{ }^{13} \mathrm{C}$ long-range couplings from a methylene proton $1-\mathrm{H}$ $\left(\delta_{\mathrm{H}} 3.54\right)$ to aromatic carbons $\mathrm{C}-1^{\prime}\left(\delta_{\mathrm{C}} 148.0\right)$ and $\mathrm{C}-2^{\prime}\left(\delta_{\mathrm{C}}\right.$ 115.9). In the $\mathrm{HMBC}$ spectra, ${ }^{1} \mathrm{H}-{ }^{13} \mathrm{C}$ long-range couplings from a methyl proton $2^{\prime}-\mathrm{Me}\left(\delta_{\mathrm{H}} 2.04\right)$ to $\mathrm{C}-1^{\prime}, \mathrm{C}-2^{\prime}$ and $\mathrm{C}-$ $3^{\prime}\left(\delta_{\mathrm{C}} 175.7\right)$ were observed. According to the ${ }^{13} \mathrm{C}$ chemical shift value of $\mathrm{C}-3^{\prime}$, the methyl residue was deduced to be placed at $\mathrm{C}-2^{\prime}$. A long-range coupling between an aromatic proton $4^{\prime}-\mathrm{H}\left(\delta_{\mathrm{H}} 6.40\right)$ and $\mathrm{C}-2^{\prime}$ was observed. In addition, the methoxyl proton $5^{\prime}-O-\mathrm{Me}\left(\delta_{\mathrm{H}} 3.85\right)$ was found longrange coupled to $\mathrm{C}-5^{\prime}\left(\delta_{\mathrm{C}} 159.6\right)$, of which ${ }^{13} \mathrm{C}$-chemical shift is almost identical to that of Mer-A2026A $\left(\delta_{\mathrm{C}} 160.4\right)$ [8]. Therefore, the pyridone moiety of $\mathbf{1}$ was established as shown in Fig. 2A. The geometry of olefins was deduced to be $2 E, 5 E, 7 E, 11 E, 13 E$-form, respectively, based on the ROE correlations between 1-H and 3-Me, 2- $\mathrm{H}$ and 4-H, 4$\mathrm{H}$ and 6-H, 6-H and 8- H, 7-Me and 9-H, and 10- $\mathrm{H}$ and $12-$ $\mathrm{H}$, along with NOE between $12-\mathrm{H}$ and $14-\mathrm{H}$. In the same manner, a 4-hydroxypyridine tautomer was also determined as shown in Fig. 2B. Thus, the structure of $\mathbf{1}$ was concluded $3: 1$ ratio of tautomeric mixture as shown in Fig. 1.

We found that $\mathbf{1}$ and $\mathbf{2}$ inhibited the export of $\beta$-arrestin 2-EYFP (Enhanced Yellow Fluorescent Protein) fusion protein from nuclear in HeLa cells at a concentration of 20 and $40 \mu \mathrm{M}$, respectively (Fig. 3). Surprisingly, 3 did not 
Table $2{ }^{1} \mathrm{H}(500 \mathrm{MHz})$ and ${ }^{13} \mathrm{C}(125 \mathrm{MHz}) \mathrm{NMR}$ data of $\mathbf{1}$ in $\mathrm{CDCl}_{3}$

\begin{tabular}{|c|c|c|c|c|c|}
\hline \multicolumn{3}{|c|}{ Pyridone form (major tautomer) } & \multicolumn{3}{|c|}{ Hydroxypyridine form (minor tautomer) } \\
\hline & Proton & Carbon & & Proton & Carbon \\
\hline 1 & $3.54(d, 6.9)$ & 30.6 & 1 & $3.49(d, 6.8)$ & 35.1 \\
\hline 2 & $5.23(t, 6.1)$ & 121.5 & 2 & 5.42 (overlap H-14) & 118.3 \\
\hline 3 & & 139.9 & 3 & & 135.8 \\
\hline 4 & $2.81(d, 6.8)$ & 43.1 & 4 & $2.80(d, 6.6)$ & 43.2 \\
\hline 5 & $5.54(\mathrm{dt}, 15.7,6.9)$ & 125.5 & 5 & $5.60(\mathrm{dt}, 15.7,7.0)$ & 126.7 \\
\hline 6 & $6.09(d, 15.7)$ & 136.7 & 6 & $6.10(d, 15.4)$ & 136.0 \\
\hline 7 & & 135.6 & 7 & & 136.1 \\
\hline 8 & $5.26(d, 9.8)$ & 134.1 & 8 & $5.23(\mathrm{~m})$ & 133.4 \\
\hline 9 & 2.71 (ddq-like) & 37.1 & 9 & 2.71 (ddq-like) & 37.2 \\
\hline 10 & $3.66(d, 8.8)$ & 83.6 & 10 & $3.64(d, 9.1)$ & 83.5 \\
\hline 11 & & 134.2 & 11 & & 134.2 \\
\hline 12 & 5.84 (br s) & 132.9 & 12 & 5.84 (br s) & 132.8 \\
\hline 13 & & 133.1 & 13 & & 133.1 \\
\hline 14 & $5.41(\mathrm{qd}, 6.8,1.2)$ & 124.9 & 14 & $5.41(\mathrm{qd}, 6.8,1.2)$ & 124.8 \\
\hline 15 & $1.69(d, 6.9)$ & 13.8 & 15 & $1.69(d, 6.9)$ & 13.8 \\
\hline $1^{\prime}$ & & 148.0 & $1^{\prime}$ & & 159.2 \\
\hline $2^{\prime}$ & & 115.9 & $2^{\prime}$ & & 116.7 \\
\hline $3^{\prime}$ & & 175.7 & $3^{\prime}$ & & 158.1 \\
\hline $4^{\prime}$ & 6.40 (br s) & 92.2 & $4^{\prime}$ & $6.50(\mathrm{~s})$ & 100.2 \\
\hline $5^{\prime}$ & & 159.6 & $5^{\prime}$ & & 162.6 \\
\hline 3-Me & $1.74(d, 1.2)$ & 16.9 & 3-Me & 1.75 (br s) & 16.8 \\
\hline 7-Me & $1.79(\mathrm{~d}, 1.2)$ & 13.29 & 7-Me & $1.80(d, 1.2)$ & 13.34 \\
\hline 9-Me & $0.84(d, 6.6)$ & 17.7 & 9-Me & $0.84(d, 6.6)$ & 17.6 \\
\hline 11-Me & 1.78 (br s) & 12.7 & 11-Me & 1.78 (br s) & 12.7 \\
\hline 13-Me & 1.74 (br s) & 16.7 & 13-Me & 1.74 (br s) & 16.7 \\
\hline $2^{\prime}-\mathrm{Me}$ & $2.04(\mathrm{~s})$ & 10.1 & 2'-Me & $2.14(\mathrm{~s})$ & 10.8 \\
\hline 5'-O-Me & 3.85 (s) & 56.3 & 5'-O-Me & 3.91 (s) & 53.8 \\
\hline
\end{tabular}

${ }^{a}$ The tautomeric mixture of compound $\mathbf{1}$ was displayed two set of signals in $3: 1$ ratio of intensity.

A

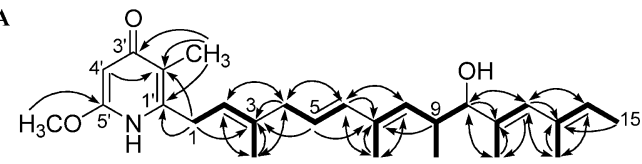

B

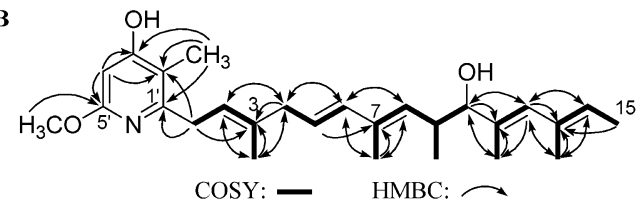

C

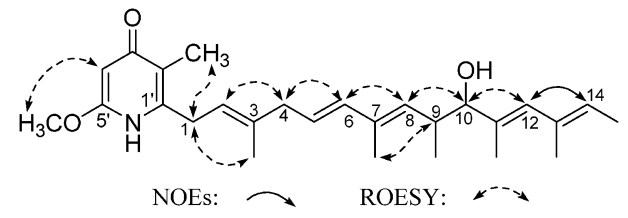

Fig. 2 Key correlations in 2D NMR (A, B: ${ }^{1} \mathrm{H}-{ }^{1} \mathrm{H}$ COSY and $\mathrm{HMBC}$; C: ROESY and NOE) experiments of JBIR-02 (1). show nuclear export inhibition at the concentration of $80 \mu \mathrm{M}$ (Fig. 3). However, we could not examine inhibitory activity of $\mathbf{3}$ at a high concentration because $\mathbf{3}$ induced cell death for HeLa cells at more than $80 \mu \mathrm{M}$ (data not shown). The compound $\mathbf{3}$ might inhibit the export of $\beta$-arrestin 2 from nuclear if another cell line except HeLa cells is treated with $\mathbf{3}$ at a high concentration. Leptomycin, another nuclear export inhibitor, can undergo a Michael-type addition by Cysteine-529 on the exportin CRM1 $[9,10]$. This covalent modification inhibits binding between chromosomal region maintenance (CRM1) and the nuclear export signal (NES)-containing cargo. Leptomycin B showed nuclear export inhibition of $\beta$-arrestin 2-EYFP at the concentration of $5 \mathrm{nM}$ (data not shown). Contrary to leptomycin, the hydroxypyridine form of $\mathbf{1}$ and $\mathbf{2}$ could not make covalent bond to CRM1 by Michael-type addition. Also, if Michael addition to the Cys-residue occurs on the 


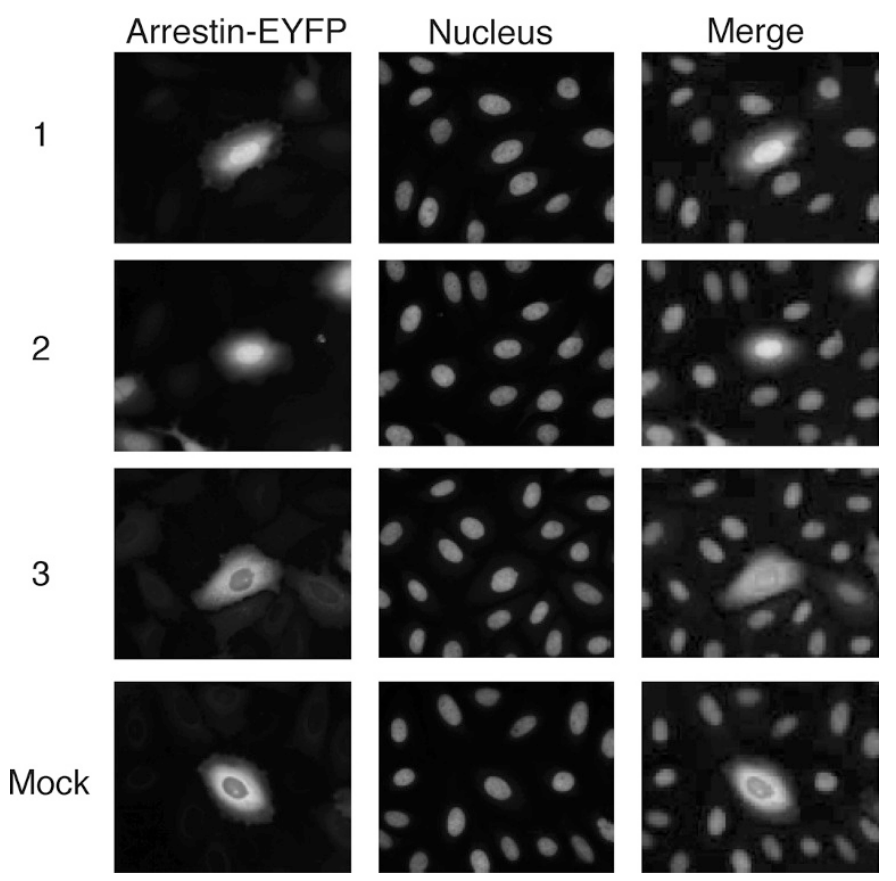

Fig. 3 Inhibition of nuclear export by JBIR-02 (1), piericidin $A_{1}(\mathbf{2})$ and IT-143-B (3).

HeLa cells were transfected by a $\beta$-arrestin 2-EYFP plasmid (expression plasmid of fusion protein of $\beta$-arrestin 2 and Enhanced Yellow Fluorescent Protein). Forty two hours after transfection, compounds (1 $\sim \mathbf{3})$ were added to the cells at the concentration of 20 , 40 and $80 \mu \mathrm{M}$, respectively. Moreover, 3 hours after addition, the cells were viewed under fluorescence microscope. Nuclei were stained with Hoechst33342.

pyridone-ring of $\mathbf{1}$, the hypothetical Cys adduct might be energetically unfavorable product because the aromaticity of pyridone-ring would lose. Accordingly, the inhibitory activities of $\mathbf{1}$ and $\mathbf{2}$ are very weak compared with leptomycin B. However, $\mathbf{1}$ and $\mathbf{2}$ possibly might act on the pocket which leptomycin covalently binds to CRM1, since they are structurally resembled leptomycin consisting of an aromatic 6-membered ring moiety with branched side chain. Studies on detailed biological activities of $\mathbf{1}$ and $\mathbf{2}$ are now underway.

Acknowledgements This work was supported by the grant from the New Energy and Industrial Technology Development Organization (NEDO) of Japan.

\section{References}

1. Ferguson SS, Downey WE 3rd, Colapietro AM, Barak LS, Menard L, Caron MG. Role of $\beta$-arrestin in mediating agonist-promoted $\mathrm{G}$ protein-coupled receptor internalization. Science 271: 363-366 (1996)

2. Lohse MJ, Benovic JL, Codina J, Caron MG, Lefkowitz RJ. $\beta$-Arrestin: a protein that regulates $\beta$-adrenergic receptor function. Science 248: 1547-1550 (1990)

3. DeWire SM, Ahn S, Lefkowitz RJ, Shenoy SK. $\beta$-Arrestins and cell signaling. Annu Rev Physiol 69: 483-510 (2007)

4. Sacks DB. The role of scaffold proteins in MEK/ERK signalling. Biochem Soc Trans 34: 833-836 (2006)

5. Buchanan FG, DuBois RN. Related emerging roles of betaarrestins. Cell Cycle 5: 2060-2063 (2006)

6. Schnermann MJ, Boger DL. Total synthesis of piericidin A1 and B1. J Am Chem Soc 127: 15704-15705 (2005). See also their Supporting Information.

7. Urakawa A, Sasaki T, Yoshida K, Otani T. IT-143-A and B, novel piericidin-group antibiotics produced by Streptomyces sp. J Antibiot 49: 1052-1055 (1996)

8. Kominato K, Watanabe Y, Hirano S, Kioka T, Terasawa T, Yoshioka T, Okamura K, Tone H. Mer-A2026A and B, novel piericidins with vasodilating effect. II. Physico-chemical properties and chemical structures. J Antibiot 48: 103-105 (1995)

9. Hamamoto T, Gunji S, Tsuji H, Beppu T. Leptomycins A and $\mathrm{B}$, new antifungal antibiotics. I. Taxonomy of the producing strain and their fermentation, purification and characterization. J Antibiot 36: 639-645 (1983)

10. Yashiroda Y, Yoshida M. Nucleo-cytoplasmic transport of proteins as a target for therapeutic drugs. Curr Med Chem 10: 741-748 (2003) 